\title{
6. SOME METHODOLOGY ASPECTS REGARDING THE ORGANIC DEPOSITS REMOVAL INTERVENTIONS IN THE PROTHESIS OF THE CHURCH OF DRAGOMIRNA MONASTERY
}

\author{
Bogdan Teodor Gavrilean ${ }^{62}$
}

\begin{abstract}
Less visible to the general public, the area of the Prothesis inside the sanctuary of the "Pentecost" heritage church, of Dragomirna Monastery, shows a particular casuistic due to the diversity of types of degradation recorded at the time of its restoration (2011). The dominant form is the adherent candlewax deposits, present on the surface of the paint layer in various stages of hardness. The particular state of conservation features occurring in this area, corroborated with a series of aggravating environmental factors, imposed the application of a special restoration intervention methodology in the area of the Prothesis.
\end{abstract}

Keywords: Heritage monuments, Northern Moldavia wall paintings, murals restoration, organic deposits, vandalism

\section{Introduction. General information}

The monastery of Dragomirna is a monastic complex located $12 \mathrm{~km}$ from the city of Suceava, in the village of Mitocul Dragomirnei of the homonymous commune. The monastery is registered in the Heritage List (Lista Monumentelor Istorice) of Suceava County, with the position $306^{63}$, and number LMI SV-II-a-A-05577.

The monastic compound comprises five items: the church of "Pentecost",64 built in 1609 , the chapel of "St. Nicholas" $" 65$ built in the $17^{\text {th }}$ century, the prior's house ${ }^{66}$ built in the $17^{\text {th }}$ century, the refectory ${ }^{67}$ built in 1609 and the boundary wall ${ }^{68}$ built in the $17^{\text {th }}$ century.

The profoundly original character of the "Pentecost" church, founded in the beginning of the $17^{\text {th }}$ century by the metropolitan and scholar Anastasie Crimca, is given by the unusual proportions of the building (excessively tall compared to its relative width), the artistic stone crafting of the facades (the torsade belt, the cut stone pilasters linked by ogee arches etc.), as well as by the richness and preciousness of its $17^{\text {th }}$ century frescoes, which adorn the sanctuary and the nave.

\footnotetext{
62 Lecturer PhD., "George Enescu” National University of Arts from Iași, Romania, e-mail: gavrileanbogdan@gmail.com

63 http://patrimoniu.gov.ro/images/lmi-2015/LMI-SV.pdf

${ }^{64}$ The Heritage List Number of the "Pentecost" church is LMI SV-II-m-A-05577.01.

${ }^{65}$ No. LMI SV-II-m-A-05577.02.

${ }^{66}$ No. LMI SV-II-m-A-05577.03.

${ }^{67}$ No. LMI SV-II-m-A-05577.04.

${ }^{68}$ No. LMI SV-II-m-A-05577.05.
} 

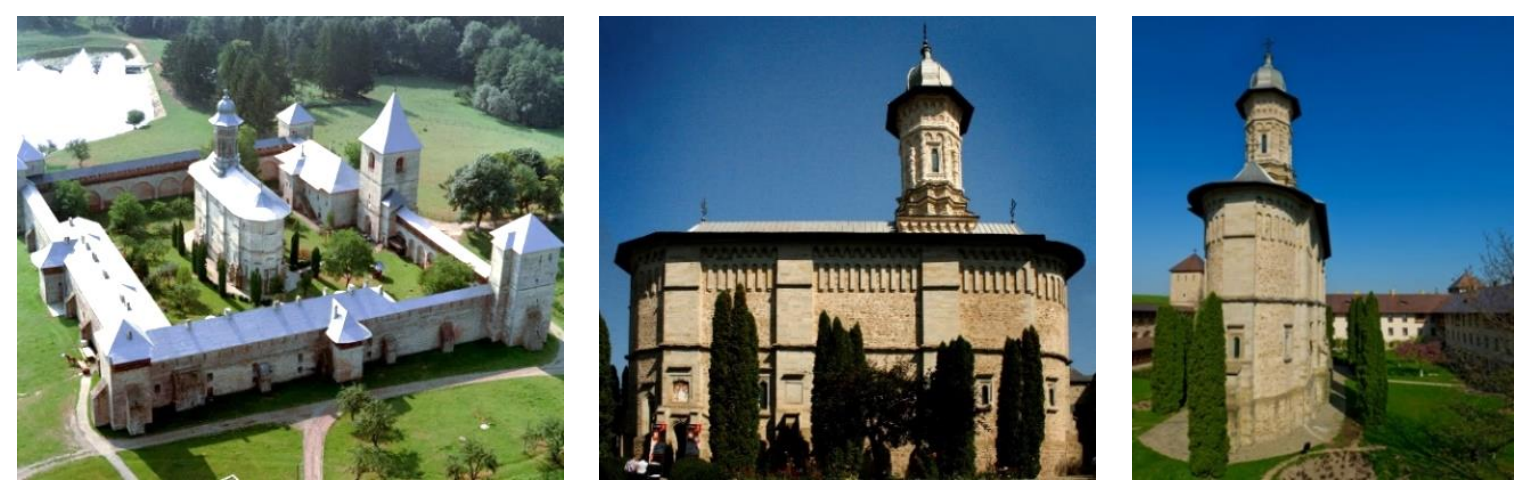

Figure 1. Aerial view of the compound; Figures 2, 3. Views of the south and south-east side

The successive repairs carried out at the end of $18^{\text {th }}$ century and during the $19^{\text {th }}$, both on the church and the boundary wall (Teodorescu \& Voinescu, 1965), as well as the new buildings raised in 1843-1845, changed, however, the original appearance of the monastery. Afterwards, the monastic compound of Dragomirna underwent restorations in several occasions, starting by 1912, and after the interruption caused by the First World War the restoration restarted in 1923-1924. There were several later interventions, in 1960-1970, although the frescoes were never included in these restoration works $^{69}$. Between 2010 and 2012, the murals in the sanctuary and the nave were restored, through the project "The restoration and preservation of the cultural heritage and the modernization of related infrastructure at the Dragomirna Monastery", funded by the Regional Operational Program. The restoration project was coordinated by art restoration professor Carmen Solomonea $\mathrm{PhD}$, and the participants included both graduates and grad students of the "Preservation-

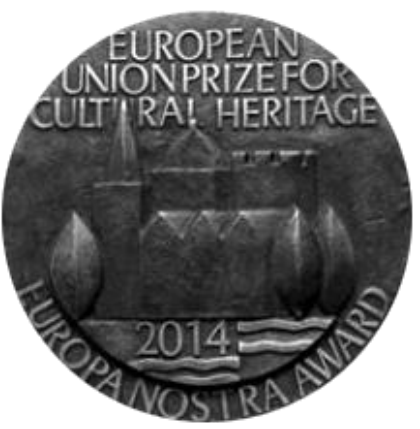

Figure 4. The Europa Nostra Award for restoration Restoration" Program of the University of Arts in Iași.

The whole murals assemblage underwent a restoration process, both scientific and state of the art, with specific operations, which facilitated the eventuality of full aesthetical recovery of the paintings. This large project included both aesthetic and research sides, in order to understand the phenomena that affected the wall painting and its evolution over time, as the state of conservation of these surfaces concealed the chromatic and compositional amplitude of the painted images ${ }^{70}$. The quality of the restoration works of this project was recognized by the award of the Grand Prize of the European Union for Cultural Heritage (the Europa Nostra Award) ${ }^{71}$, in 2014 , in the category of Preservation, as well as by the Public Award, following an online vote with more than 10,000 participants ${ }^{72}$.

\footnotetext{
69 http://www.mdrap.ro/comunicare/presa/comunicate/frescele-bisericii-dragomirna-restaurate-prin-regio-auprimit-marele-premiu-al-ue-si-premiul-publicului

${ }^{70}$ Solomonea, Carmen, Biserica „Pogorârea Sfântului Duh” a mănăstirii Dragomirna, conservarea şi restaurarea picturilor murale, in ACS: http://acs.org.ro/ro/conservare/338-manastirea-dragomirna-conservare-sirestaurare?start=6.

${ }^{71} \mathrm{http}: / / \mathrm{www}$.europanostra.org/awards/133/

72 Source: http://europedirect-adrcentru.ro/index.php/stiri-uniunea-europeana/285-frescele-bisericii-dragomirnarestaurate-prin-regio-printre-castigatorii-premiilor-europa-nostra-201
} 


\section{The localization of the intervention area - the Prothesis}

The restoration interventions that are the scope of this paper were carried out in the prosthesis of the church, a liturgical space in the form of niche, apse, alcove or even a square of floor with a small table on top, located on the north side of the sanctuary (Braniște, 1993, p. 396), which serves as a depository of the liturgical vessels (chalice, diskos etc.). The Eucharistic bread and wine brought by the faithful are set here by the priest before being consecrated during the Holy Eucharist.

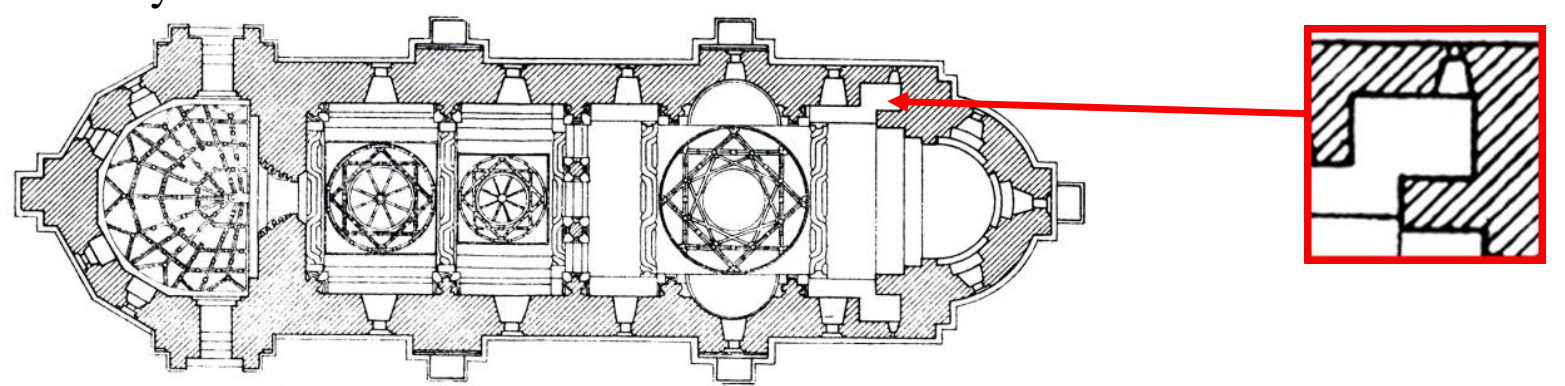

Figure 5. The localization of the intervention area on the ground plan

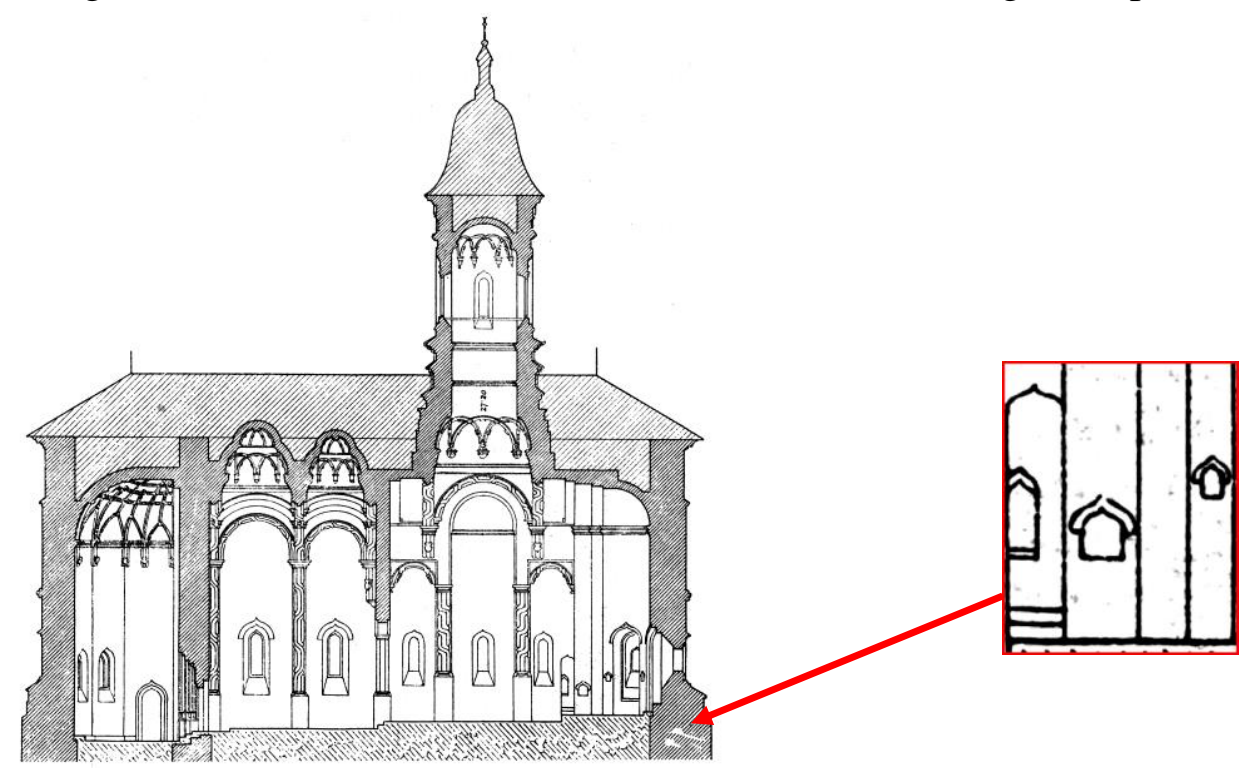

Figure 6. The localization of the intervention area on the axial section

\section{The state of conservation of Prothesis murals}

The whole surface of the paint layer on the walls of the Prothesis show extensive regions covered by an opaque black layer of dust, spider webs, smoke and tars, which drastically obscured the visibility of the wall painting decoration ${ }^{73}$. Multiple types of foreign metallic materials were also identified, embedded in the structure of the preparation layers on the occasion of various "modernization" operations that affected the Prothesis, which operations culminated in the forceful insertion of a marble slab as washing table, in a space cut into the original fresco.

\footnotetext{
73 "Inside the Orthodox churches, the largest deposits [of soot n.a.] occur [...] in the nave and sanctuary". Oliviu Boldura (2007), Pictura murală din nordul Moldovei. Modificări estetice şi restaurare, Accent Print, Suceava. p.25.
} 

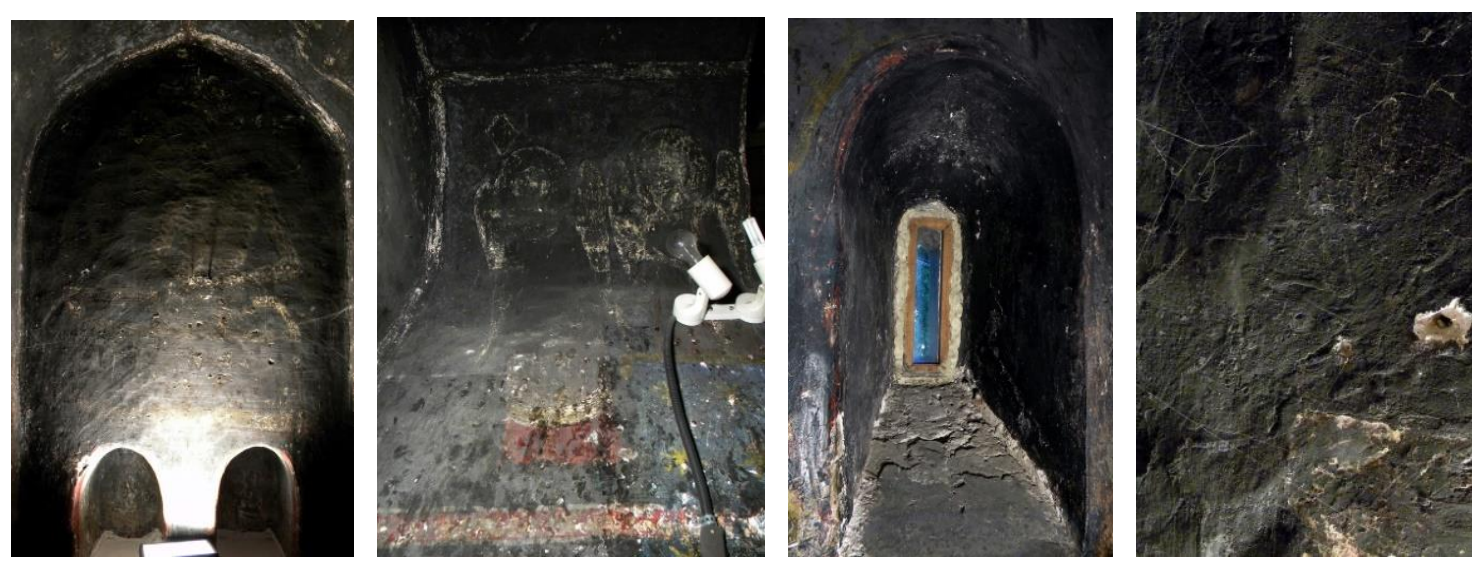

Figures 7, 8, 9. Opaque layers of superficial deposits on the scene "Christ in the tomb", on the inner face of the vaulting, also in the window on the north wall. Figure 10. Spider webs detail
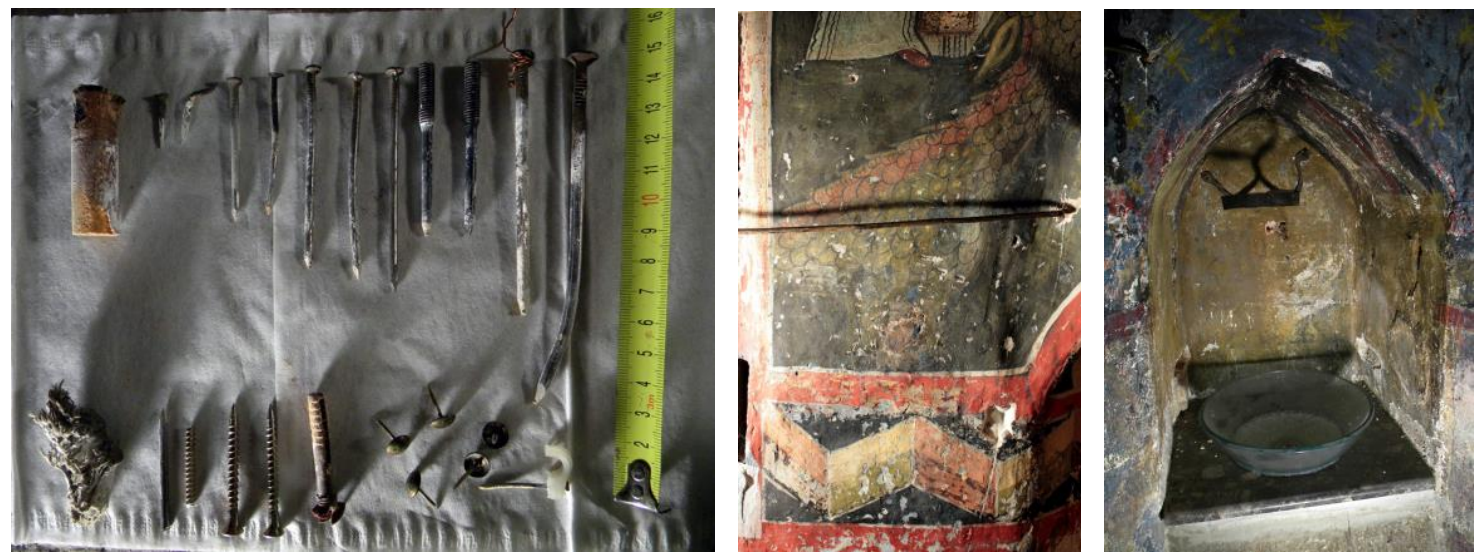

Figure 11. Foreign metallic materials taken out from the fresco Figure 12. Improvised towel rack. Figure 13. The abusive "modernization" of the washing table

One of the aggravating collateral factors in the precarious state of conservation in the area of the Prothesis is the presence of technical faults in the execution of the murals, regarding both the negligent application of the paint in less visible areas and painting mistakes proper.
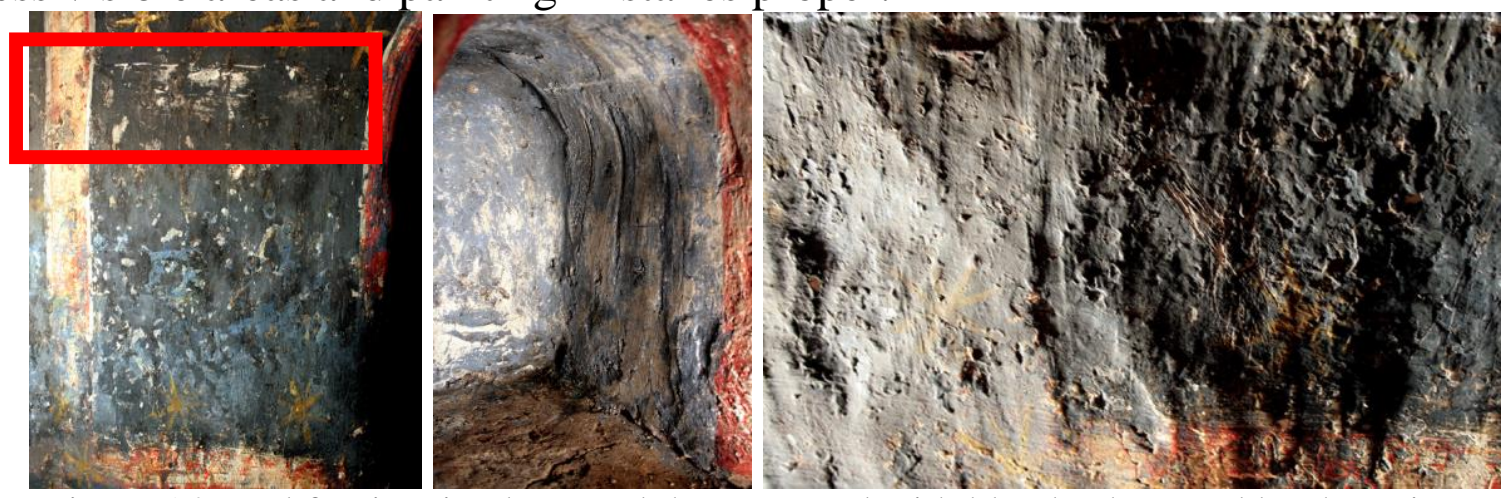

Figure 14. Red fascia wiped out and then covered with blue background by the painter

Figure 15. The negligent application of fresco on the lower niches

Figure 16. Detail of fresco application for the blue background

On almost the whole surface of the paint layer there were identified waxes of different types and degrees of strength, from "simple" drops or drips of melted wax, to layers of significant density on the side walls. In the case of median area of the north wall, the wax is deposited as "raindrops", while on the south wall the wax deposit is a thick, stratified layer, with polished surface and localized insertions of textile fibers. 

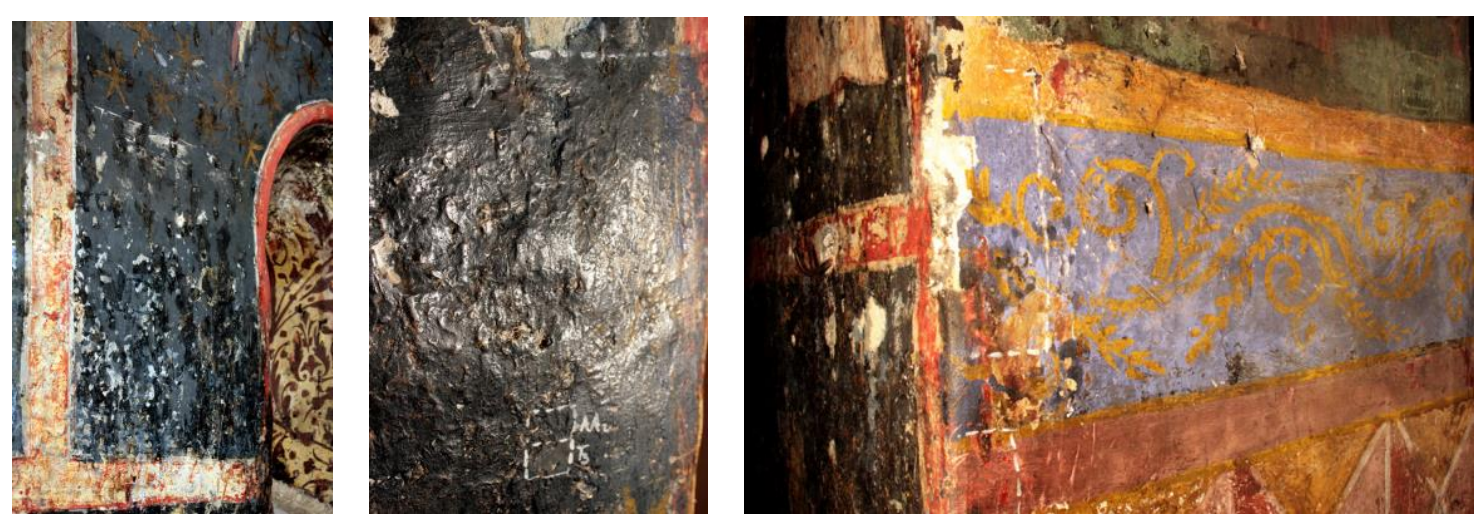

Figure 17. The "raindrops" wax deposits on the north wall Figures 18, 19. Stratified and polished wax deposits; Repainting using protein-based paint in the area of the ornamental belt

The analysis of the state of conservation also identified a series of localized repainting using protein-based paints (the ornamental belt, several architectural elements) that, in some cases, completely cover the wax deposits, as well as grouting of the preparation layers, made using a variety of improper materials (certain lacunae were "stuffed" with paper and then grouted over using a sand-based mortar, while several areas near the window in the north wall were grouted using hard Portland cement mortars etc.).
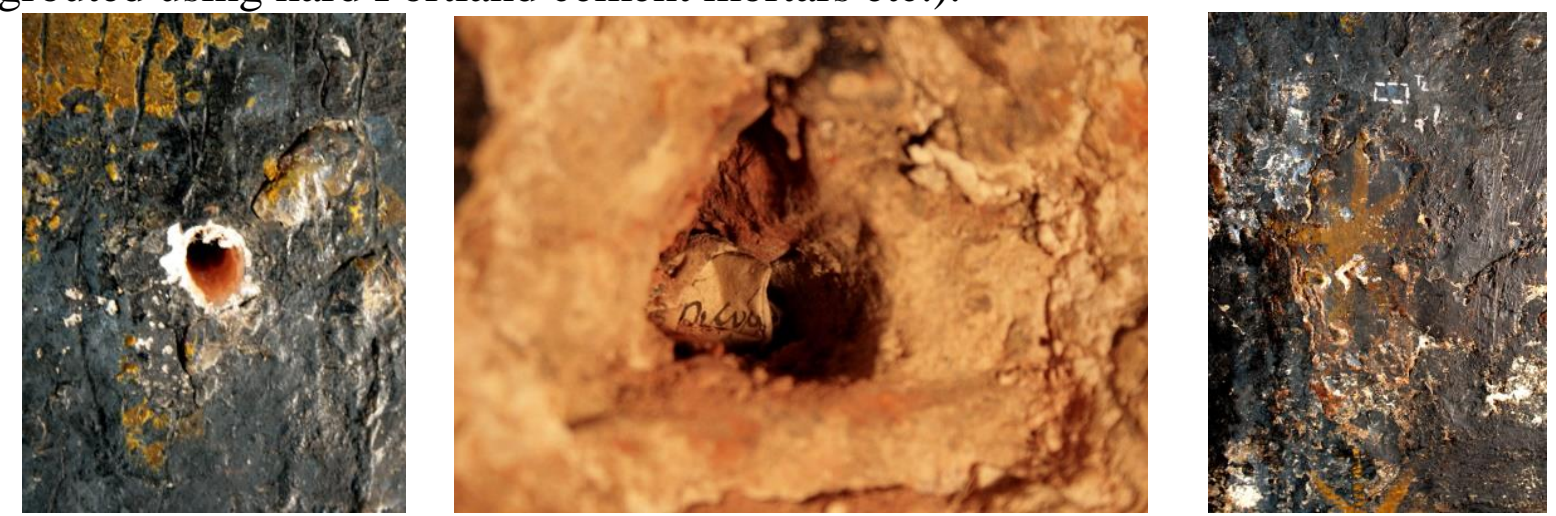

Figure 20. Wax deposits repainted Figure 21. Lacuna filled with paper Figure 22. Grouting with improper materials, covered by wax deposits, then painted over using protein-based paints

In order to complete the overview of the state of conservation in the Prothesis, one should include, as aggravating factors, the issue of flaking of the paint layer, combined with localized lack of adhesion of the pigments to the paint layer, which pulverization determined an intervention approach adequate to the situation.
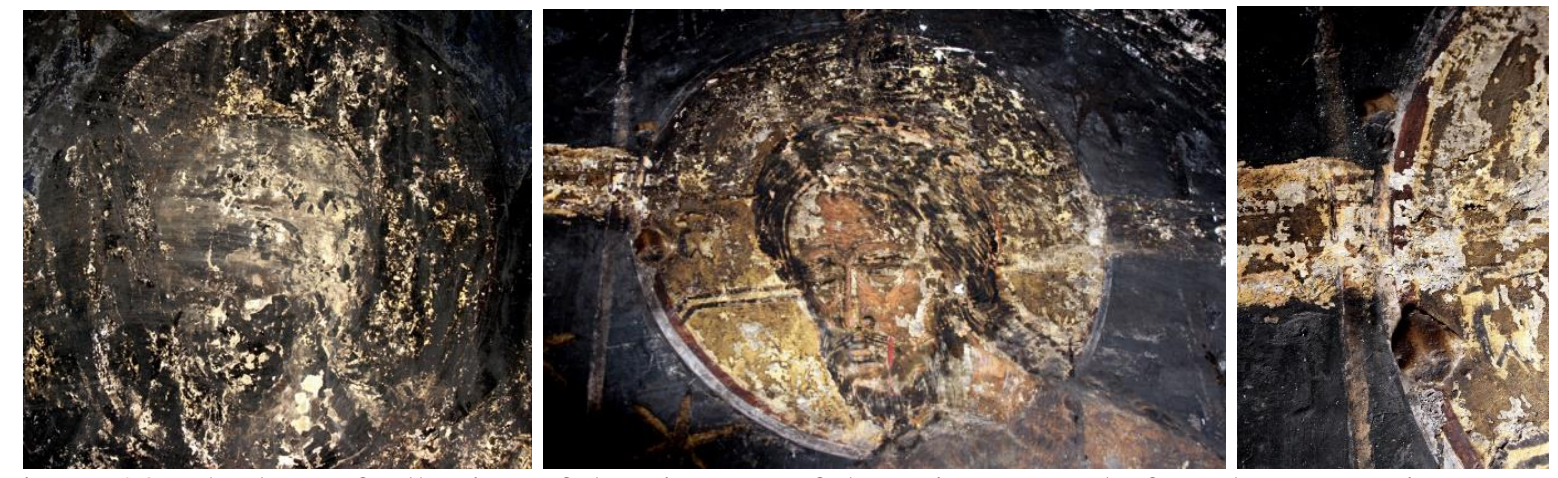

Figure 23. The loss of adhesion of the pigment of the paint payer, before the restoration Figures 24, 25. Flaking and pulverization of pigments, after the first cleaning intervention 


\section{Restoration intervention methodology employed inside the Prothesis}

Following the visual non-destructive investigation, using direct and raking light, which identified the main types of degradation present both on the paint layer and the preparation layers, the next step consisted in testing the adhesion to the paint layer of pigments and other potentially detaching elements, by lightly rolling a cotton-tipped bamboo stick ${ }^{74}$, moistened with a $10 \% \mathrm{AA}^{75}$ solution, over the surface of the affected areas. According to the results of these tests, the first restoration operation consisted in the selective unloading of superficial airborne deposits, by means of soft-haired paint brushes, with special care required in the area of the Christ and angels portraits on the inner face of the vaulting, which were affected by paint layer flaking and massive pulverization.
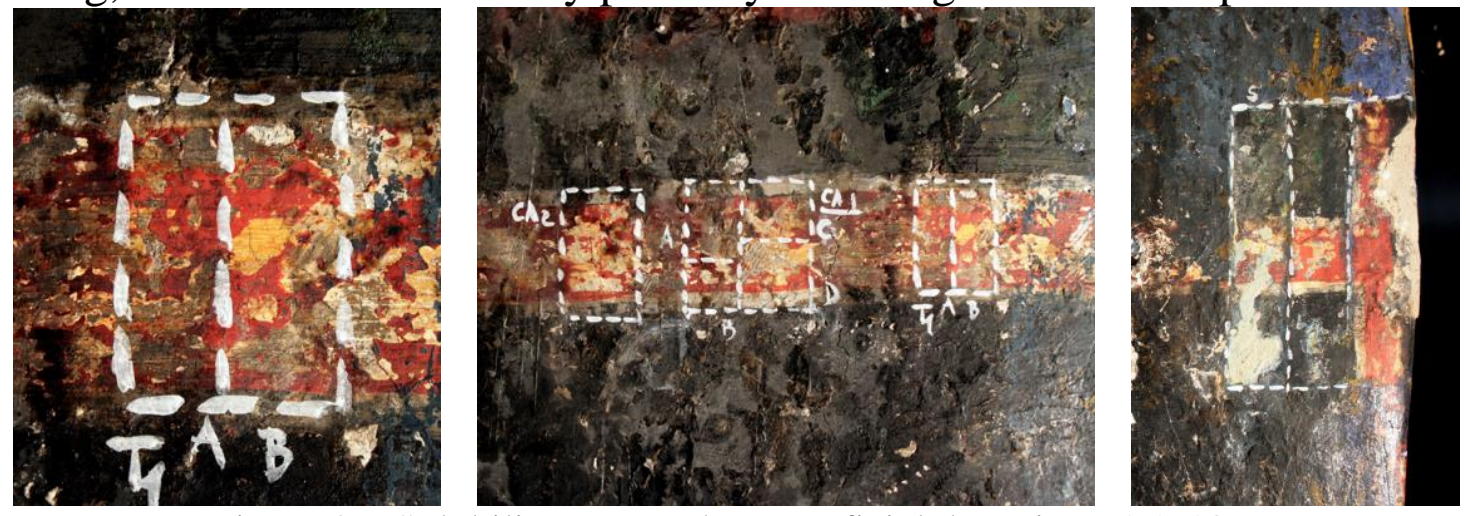

Figure 26. Solubility test on the superficial deposits - AA 10\%

Figures 27, 28. Combined (chemical and mechanical) tests for the removal of lightly adhering deposits, using $\mathrm{CA}^{76} 5-10 \%$ and solvents

Afterwards, several more deposit removal tests were carried out on the surface of the paint layer, using various solution concentration values, on successive rectangular test areas, combining different methods (chemical, mechanical or combined) according to the state of preservation of the surface. Consequently, the most effective intervention options were established, function of the results, bearing the lowest degree of risk to the paint layer surface.

Therefore, the areas with pigments sensible to acid or alkaline solutions ${ }^{77}$, as well as the gilded areas were cleaned using AA solution, applied locally by cotton-tipped bamboo sticks, or by brushing the solution on $\mathrm{pH}$-neutral paper pads, according to the characteristics of the surface. Special precautions were taken in the case of areas with flaking or pulverization (on the portrait in the scene "Christ in the tomb"), which required firstly the re-leveling of detached paint layer areas, by pressing-down with rubber rollers, through AAimpregnated Japanese paper pads. These areas were cleaned afterwards using also 10\% AA solution on Japanese paper pads, reapplied at intervals sufficiently large to allow the partial re-adhesion to the paint layer of the flaked areas.

In the case of wax deposits, two distinct methods were employed: a) on the areas with stable paint layer, the thick wax deposits were removed by mechanical means, in successive stages, then the remaining fine film would be

\footnotetext{
74 „Bastoncini”.

${ }^{75}$ Water and ethanol solution, analysis reagent.

${ }^{76}$ Ammonium carbonate and de-mineralized water solution.

${ }^{77}$ Like enamel-blue identified on certain areas over the blue background.
} 
softened and removed by chemical means, by localized dabbing with xylenetype solvents and Solvapeint ${ }^{\mathrm{TM}}$; b) on the areas with unstable paint layer, the wax was softened and then removed exclusively by chemical methods: the solvents were applied locally, in successive stages, by means of $\mathrm{pH}$-neutral paper film or paper paste pads, in order to avoid the risk of detaching the paint film.
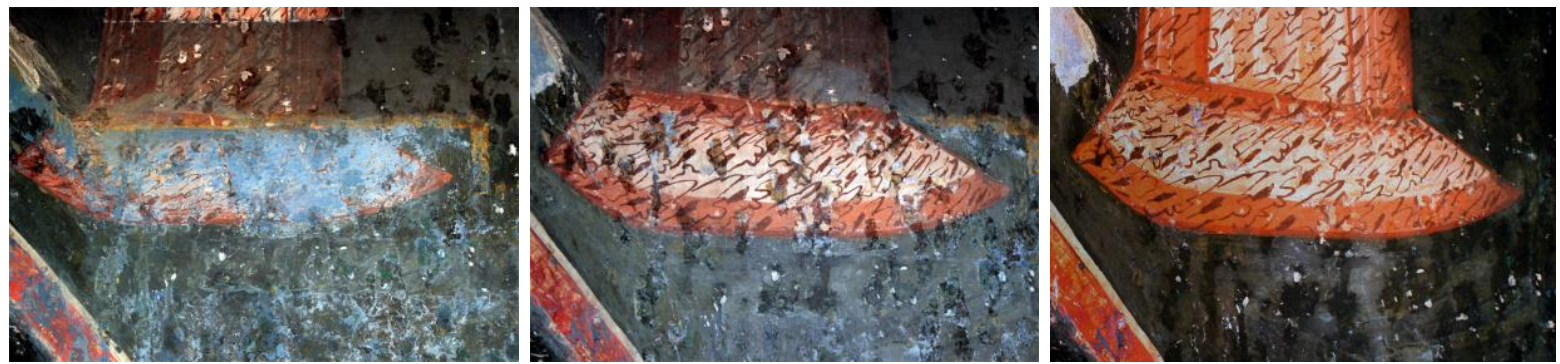

Figures 29 - 33. The successive stages of removal of wax and foreign materials deposits from the paint layer of the north (up) and west (down) walls in the Prothesis

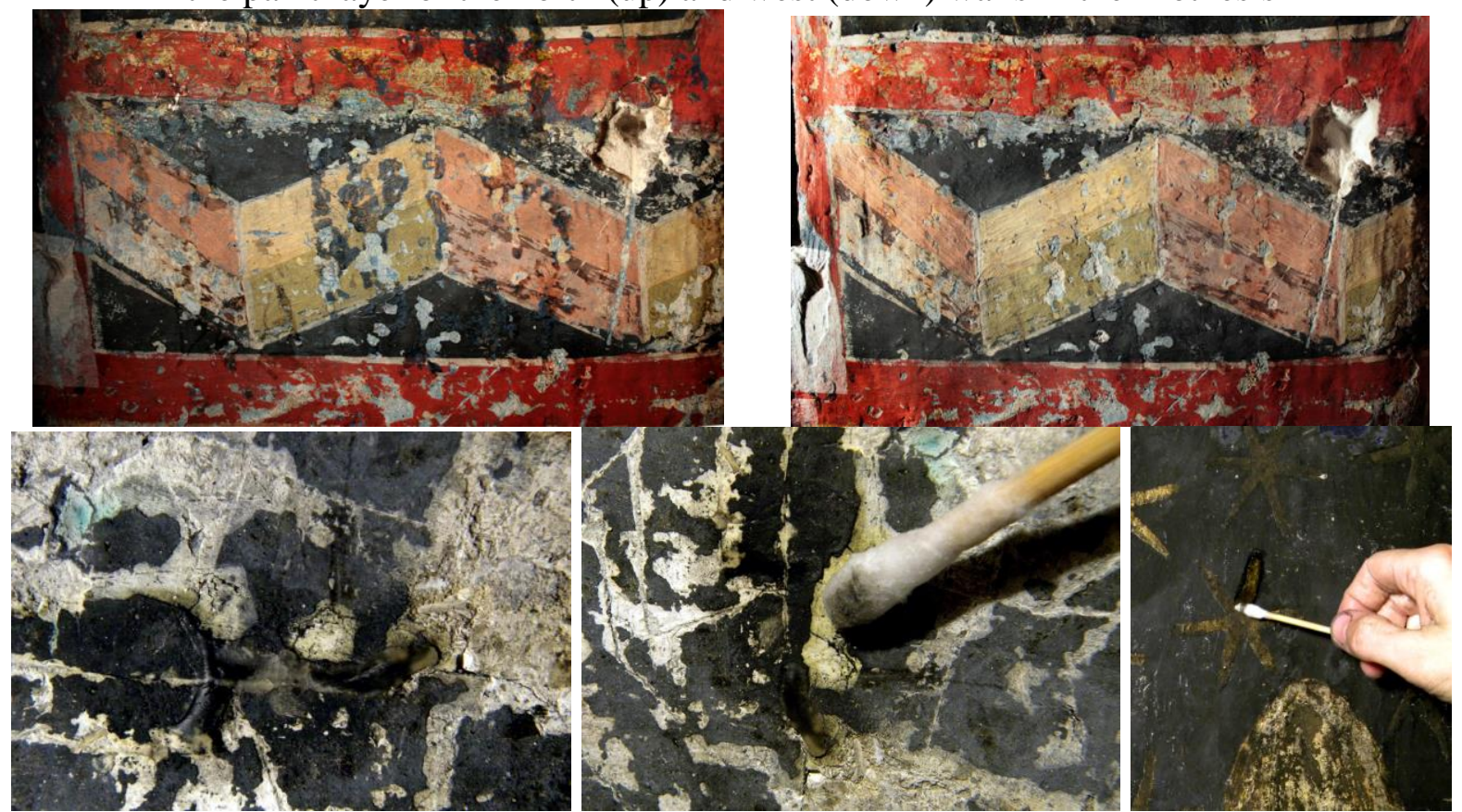

Figure 34. Wax deposits on unstable paint layer

Figure 35. Localized softening of wax deposits. Figure 36. Cleaning the gilding with 10\% AA solution
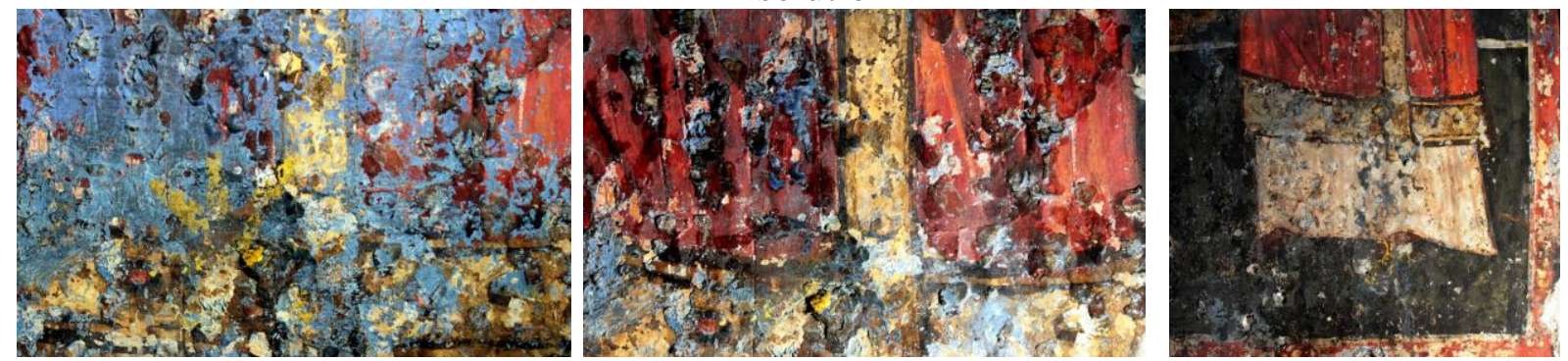

Figures $37-39$. The south wall of the Prothesis: wax and resin deposits, covered by repainting hardened over time, operations during the restoration intervention

A very particular casuistic occurred in the area of the small window in the north wall: the inner face of its vaulting was covered by a combination of resin, tar and salt incrustation deposits, hardened by time and by the severe microclimate variations occurring in that space. The removal of these deposits required recurring interventions over several days intervals, using low- 
concentration CA solution on paper pads acting though on longer periods. The eventual softening of the deposits was followed by mechanical removal means, i.e. scalpels and bastoncini.
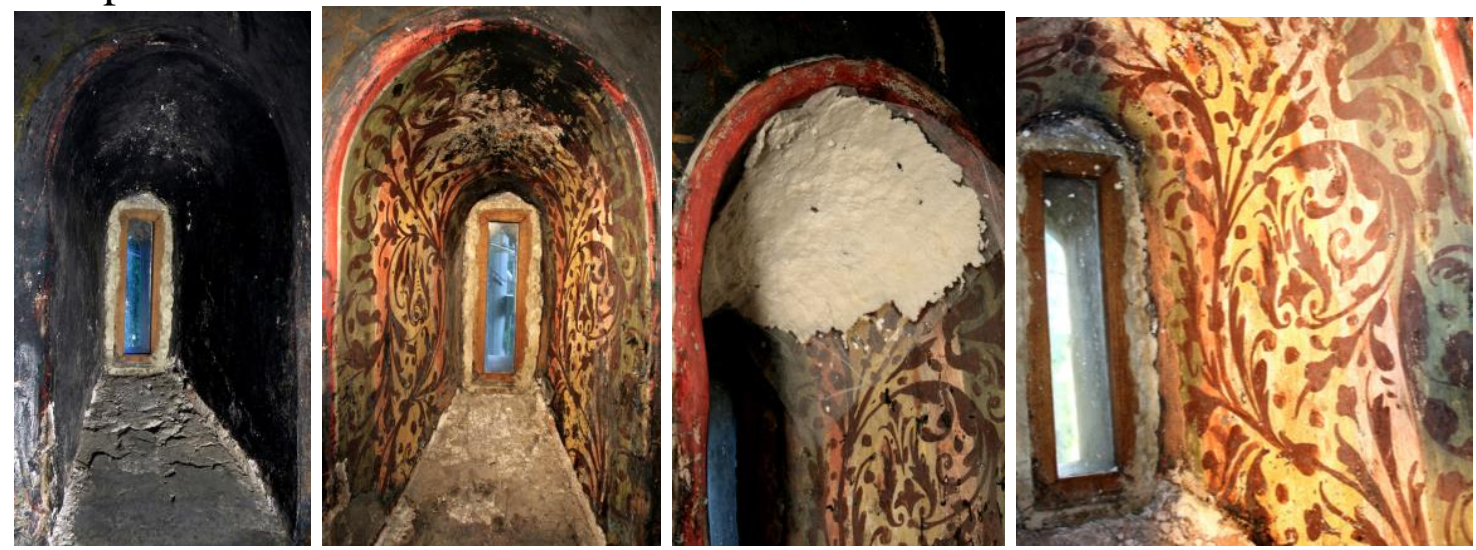

Figures $40-43$. The small window in the north wall of the Prothesis: the initial state of preservation (left) and the successive stages of removal of hardened deposits from the surface of the paint layer

\section{Conclusions. Final considerations}

Behind the restoration of each monument brought back into the circuit of Romanian national specific artistic and cultural values, is the continuous and assiduous labors of the restorers, whose efforts toward repairing the damages of time, on one hand, and human negligence and vandalism, on the other, is seldom acknowledged by the public at large. Only by knowing and promoting the history of monuments, including the

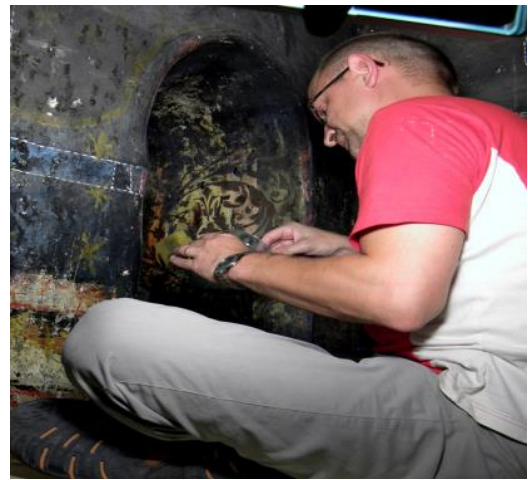

Figure 44. The body posture of the restorer during the restoration intervention recent history that encompasses the restoration interventions, shall be possible to justly appreciate the value of our national cultural heritage treasures, and be able to hand over to the youger generations, of yesterday, today and tomorrow, our passion for these profoundly Romanian values.

\section{Bibliography}

1. Balș, G. (1933). Bisericile și mănăstirile din veacurile al XVII-lea și al XVIII-lea (3rd vol.). București: Institutul de Arte Grafice „E. Marvan”

2. Boldura, O. (2007). Pictura murală din nordul Moldovei. Modificări estetice și restaurare. Suceava: Accent Print.

3. Bordașiu, C. (2010). Estetică și restaurare. Iași: StudIS.

4. Braniște, E. (1993). Liturgica generală. București.

5. Gavrilean, B. \& Ungurean, B. (2004). Depuneri de materii organice dure pe suprafața decorațiilor murale de la biserica Mănăstirii Popăuți-Botoșani. In Monumentul, Tradiție şi viitor, Proceedings of the $5^{\text {th }}$ edition, Iași: Trinitas.

6. Gavrilean, B. (2005). Intervențiile umane ca factor de degradare - studiu de caz la scena „Lepădarea lui Petru” din absida sudică a bisericii Mănăstirii Popăuți - Botoşani. In Monumentul, Tradiție şi viitor, Proceedings of the $6^{\text {th }}$ edition. Iași: Trinitas. 
7. Istudor, I. (2011). Noțiuni de chimia picturii ( $3^{\text {rd }}$ edition), Art Conservation Support.

8. Melniciuc-Puică, N. (2001). Materiale pentru realizarea, conservarea şi restaurarea icoanelor și a frescelor. Iași: Tehnopress.

9. Moldoveanu, A. (1999). Conservarea Preventivă a bunurilor culturale, (Vol. 1-2). București: Centrul de pregătire și formare a personalului din instituțiile de cultură.

10. Mora, P., Mora, L., Philippot, P. (1986). Conservarea picturilor murale. București: Meridiane.

11. Solomonea, C. (2006). Saint Nicholas Church of Popăuți Monastery Botoșani. Revista Monumentelor Istorice, 75(1-2).

12. Solomonea, C. (2008). Aspecte privind starea de conservare și intervenții de restaurare a picturii murale de la biserica „Sfântul Nicolae” a mănăstirii Popăuți - Botoșani. Revista Monumentelor Istorice, 1-2.

13. Solomonea, C. (2009). Voroneț, Popăuți, Probota și Moldovița. Metode tehnice ale picturii murale. Iași: Artes.

14. Solomonea, C. Biserica „Pogorârea Sfântului Duh” a mănăstirii Dragomirna, conservarea şi restaurarea picturilor murale, in ACS: http://acs.org.ro/ro/conservare/338-manastirea-dragomirna-conservare-sirestaurare? start $=1$.

15. Teodorescu, R. \& Voinescu, T. (1965). Mănăstirea Dragomirna, București: Meridiane.

\section{Online resources:}

1. *** ACS: http://acs.org.ro/

2. *** Europa Nostra: http://www.europanostra.org

3. *** The Heritage List (Lista Monumentelor istorice) of Suceava Co.: http://patrimoniu.gov.ro

4. *** Monastery of Dragomirna: http://manastireadragomirna.ro

5. *** Normative Regulation for the Preservation and restoration of registered mobile cultural heritage items (2003): http://cultura.ro;

6. *** Normative Regulation for the Preservation and restoration of registered mobile cultural items approved by HG no. 886/2008: http://cultura.ro;

\section{Illustration sources:}

Figure 1: http://adrianexcelent.deviantart.com/art/Manastirea-Dragomirna;

Figures 2, 3: Gavrilean Bogdan (processed images);

Figure 4: http://www.mdrap.ro/;

Figures 5, 6: G. Balș (1933), „Bisericile și mănăstirile din veacurile al XVII-lea și al XVIII-lea”, vol. 3, Institutul de Arte Grafice „E. Marvan”, Bucharest, p. 27 (processed images);

Figures 7-11: Oprea Andrei

Figures 12-34: Gavrilean Bogdan (processed images);

Figures 35-36: Oprea Andrei

Figures 37-43: Gavrilean Bogdan (processed images).

Figure 44: Oprea Andrei. 